\title{
PEMBENTUKAN PORTOFOLIO OPTIMAL DENGAN METODE RESAMPLED EFFICIENT FRONTIER UNTUK PERHITUNGAN VALUE AT RISK DILENGKAPI APLIKASI GUI MATLAB
}

\author{
Henny Setyowati ${ }^{1}$, Abdul Hoyyi ${ }^{2}$, Di Asih I Maruddani ${ }^{3}$ \\ 1,2,3 Departemen Statistika FSM Universitas Diponegoro \\ e-mail : hennysetyowati28@gmail.com
}

\begin{abstract}
The purpose of investors in investing is to get a return, but investors also have to bear the risks that might exist. There are 3 types of investors in investment based on their preference for risk, namely risk aversion (risk averter), moderate risk takers (risk moderate), and high risk takers (risk takers). To obtain an optimal portfolio for each type of investor, the Resampled Efficient Frontier Method is used with Monte Carlo Simulation as much as 700 times, to obtain more parameter estimates. The results of the Resampled Efficient Frontier from Efficient Frontier will take 51 efficient points to determine the optimal portfolio for each type of investor. The efficient point taken is the 1st, 26th and 51st efficient points for the investor risk averter type, risk moderate, and risk taker. To determine the estimated loss in investment, the VaR value is calculated based on the monthly return data of BBNI, UNTR, INKP, and KLBF shares for the period February 2013 to March 2017, with a capital allocation of Rp 100,000,000.00, a holding period of 20 days, and a level of trust of $95 \%$. The Matlab GUI is used to facilitate users in processing data.
\end{abstract}

Keywords: Efficient Frontier, Monte-Carlo Simulation, Normal Distribution, VaR, Matlab GUI

\section{PENDAHULUAN}

Investasi di pasar modal dalam bentuk portofolio memberikan ekspektasi keuntungan (expected return) namun juga mengandung risiko yang mungkin akan dihadapi investor (expected risk). Untuk itu, Investor layak memperhatikan penggunaan strategi investasi tertentu dalam rangka mencapai investasi yang optimal, yaitu investasi yang dapat memberikan return tertentu dengan kandungan risiko yang dapat ditekan seminimal mungkin. Salah satu strategi yang dapat digunakan adalah dengan portfolio strategy.

Portofolio merupakan kumpulan dari instrumen investasi yang dibentuk untuk memenuhi suatu sasaran umum investasi. Dalam kondisi seperti itu, maka investor harus mampu membentuk portofolio yang efisien yaitu melakukan investasi dalam instrumen yang memberikan keuntungan yang diharapkan (expected return) tertentu dengan tingkat risiko tertentu (expected risk) tertentu yang rendah atau yang bersedia investor tanggung. Portofolio efisien tersebut sering disebut dengan efficient frontier.

Resampled Efficient Frontier adalah hasil dari menghitung rata-rata dari bobot tiap aset dalam Mean Variance Efficient Portfolio dengan tingkat return tertentu. Resampled Efficient Frontier lebih memberikan investasi yang aman dan reliabel (Michaud dan Michaud, 2008). Untuk memperbanyak input proses resampling digunakan metode Simulasi Monte-Carlo dengan menyesuaikan karakteristik informasi dari data historis yang tersedia dari data historis yang sesungguhnya. Untuk mengukur risiko dalam investasi digunakan Value at Risk (VaR). VaR merupakan perkiraan besarnya kerugian dan besarnya kemungkinan terjadinya kerugian dalam investasi. GUI MATLAB digunakan untuk mempermudah pengambilan keputusan dari hasil perhitungan bobot-bobot yang optimal serta risiko portofolio. 


\section{TINJAUAN PUSTAKA}

\subsection{Saham}

Menurut Bursa Efek Indonesia (BEI) tahun 2018, Saham dapat didefinisikan sebagai tanda penyertaan modal seseorang atau pihak (badan usaha) dalam suatu perusahaan atau perseroan terbatas.

\subsection{Pasar Modal}

Menurut Usman (1989), pasar modal adalah pelengkap di sektor keuangan terhadap dua lembaga lainnya yaitu bank dan lembaga pembiayaan. Pasar modal memberikan jasanya yaitu menjembatani hubungan antara pemilik modal dalam hal ini disebut sebagai pemodal (investor) dengan pinjaman dana dalam hal ini disebut dengan nama emiten (perusahaan yang go public).

\subsection{Return Aset}

Menurut Ang (1995), return (kembalian) adalah tingkat keuntungan yang dinikmati oleh pemodal atas suatu investasi yang dilakukannya. Menurut Amenc dan Sourd (2003), untuk mempermudahkan perhitungan, maka diasumsikan tidak ada dividen yang dibagikan selama periode investasi. Perhitungan return secara geometri dapat menggunakan persamaan berikut:

$$
R_{i t}=\ln \left(\frac{H_{i t}}{H_{i t-1}}\right)
$$

Untuk perhitungan secara aritmetiknya menggunakan persamaan berikut:

$$
R_{i t}=\left(\frac{H_{i t}-H_{i t-1}}{H_{i t-1}}\right)
$$

Jika terdapat n (jumlah observasi) return, maka ekspektasi return dapat diestimasi dengan rata-rata sampel (mean) return:

$$
E\left(R_{i}\right)=\bar{R}_{i}=\frac{1}{n} \sum_{t=1}^{n} R_{i t}
$$

$H_{\text {it }} \quad$ : harga saham i pada periode $\mathrm{t}$

$H_{i t-1}$ : harga saham i pada periode $\mathrm{t}-1$

$R_{i t} \quad$ return saham i pada periode $\mathrm{t}$

$\bar{R}_{i} \quad$ : rata-rata return saham i (expected return)

\subsection{Return Portofolio}

Menurut Fabozzi (1999), pengembalian aktual dari suatu portofolio yang terdiri dari a aset sepanjang periode waktu tertentu secara langsung dapat diperhitungkan sebagai berikut:

$R_{p}$ : return portofolio selama periode berjalan

$$
R_{p}=w_{1} R_{1}+w_{2} R_{2}+w_{3} R_{3}+\cdots+w_{a} R_{a}
$$

$R_{i}$ : return saham i selama periode berjalan

$w_{i}$ : bobot saham i dalam portofolio

i $\quad: 1,2, \ldots, \mathrm{a}$

\subsection{Varian dan Standar Deviasi}

Varian dari return suatu aset adalah ekspektasi nilai atas deviasi kuadrat dari return yang diharapkan. Sedangkan standar deviasi dari return suatu aset adalah akar dari varian 
return (Bodie, et al. 2006). Menurut Maruddani dan Purbowati (2009), varian dan standar deviasi tiap aset, perhitungannya adalah sebagai berikut:

$$
S_{i i}=S_{i}^{2}=\frac{1}{n-1} \sum_{t=1}^{n}\left(R_{i t}-\bar{R}_{i}\right)^{2}
$$

Menurut Fabozzi (1999), bagi portofolio dengan jumlah saham sebanyak a, varian portofolionya adalah:

$$
\operatorname{var}\left(R_{p}\right)=\sum_{i=1}^{a} w_{i}{ }^{2} \operatorname{var}\left(R_{i}\right)+\sum_{i=1}^{a} \sum_{j=1}^{a} w_{i} w_{j} \operatorname{cov}\left(R_{i}, R_{j}\right)=\boldsymbol{w}^{\boldsymbol{T}} \boldsymbol{S} \boldsymbol{w}
$$

$S_{i i} \quad$ : varian return saham i

$S_{i} \quad$ : standar deviasi return saham i

$\boldsymbol{S} \quad$ : matriks varian kovarian return saham dalam portofolio

$\boldsymbol{w}$ : vektor bobot saham dalam portofolio

\subsection{Risiko Portofolio}

Menurut Tandelilin (2010), risiko portofolio ditentukan lewat kontribusi aset-aset individual yang tergabung dalam portofolio terhadap risiko portofolio.Dengan menggunakan ukuran kovarian, bisa dihitung besarnya risiko portofolio, baik yang terdiri dari dua buah sekuritas maupun $n$ sekuritas.

\subsection{Kovarian}

Menurut Tandelilin (2010), kovarian adalah ukuran absolut yang menunjukkan hubungan atau keeratan dua variabel yang memiliki kecenderungan bergerak bersamasama. Suatu nilai positif kovarian mengindikasikan return sekuritas cenderung bergerak ke arah yang sama. Sedangkan kovarian negatif mengindikasikan kecenderungan return bergerak berlawanan.

\subsection{Diversifikasi}

Diversifikasi portofolio diartikan sebagai pembentukan portofolio sedemikian rupa sehingga dapat mengurangi risiko portofolio tanpa mengorbankan pengembalian yang dihasilkan. Para investor yang mengkhususkan diri dalam investasi saham, menganggap perlu dilakukan diversifikasi portofolio. Yang dimaksud dengan diversifikasi portofolio dalam hal ini adalah seluruh dana yang ada seharusnya tidak diinvestasikan ke dalam satu saham tetapi portofolio harus terdiri dari banyak saham perusahaan (Fabozzi, 1999).

\subsection{Tipe Investor}

Menurut Samsul (2006), dilihat dari kesediaannya menanggung risiko investasi, investor dapat dikategorikan menjadi 3 kelompok atau tipe, yaitu :

1. Tipe investor yang berani mengambil risiko, yang disebut risk taker. Tipe risk taker akan merasa sangat senang apabila ditawari saham yang memiliki gejolak harga yang tinggi.

2. Tipe investor yang takut atau enggan menanggung risiko, yang disebut risk averter. Tipe risk averter akan merasa senang apabila ditawari saham yang memiliki risiko rendah.

3. Tipe investor yang netral terhadap risiko, yang disebut risk moderate atau moderate investor. Tipe investor ini hanya berani menanggung risiko yang sebanding dengan return yang akan diperolehnya.

\subsection{Distribusi Normal Multivariat}

Fungsi densitas normal multivariat a dimensi untuk vektor random $\boldsymbol{X}=\left[\boldsymbol{X}_{1}, \boldsymbol{X}_{2}, \ldots, \boldsymbol{X}_{\boldsymbol{a}}\right]^{\prime}$ adalah : 


$$
f(x)=\frac{1}{(2 \pi)^{\frac{a}{2}}|\boldsymbol{S}|^{\frac{1}{2}}} \exp \left(-\frac{1}{2}(\boldsymbol{x}-\overline{\boldsymbol{x}})(\boldsymbol{S})^{-1}(\boldsymbol{x}-\overline{\boldsymbol{x}})\right)
$$

dengan $-\infty<x_{i}<\infty$

Pengujian asumsi normal multivariat juga dapat dilakukan dengan uji kecocokan distribusi Kolmogorov-Smirnov yang dikemukakan Daniel (1989). Pengujian dilakukan dengan memeriksa apakah jarak mahalanobis $\left(d_{j}^{2}\right)$ berdistribusi $X^{2}$ dengan derajat bebas a atau tidak. Berikut langkah pengujian asumsi normal multivariat :

Hipotesis:

$$
\begin{aligned}
& H_{0}: F\left(d_{j}^{2}\right)=F_{0}\left(d_{j}^{2}\right) \text { untuk semua nilai } d_{j}^{2} \\
& H_{1}: F\left(d_{j}^{2}\right) \neq F_{0}\left(d_{j}^{2}\right) \text { untuk sekurang-kurangnya sebuah nilai } d_{j}^{2}
\end{aligned}
$$

Tingkat Signifikansi: $\alpha$

Statistik Uji:

$$
D=\sup _{d_{j}^{2}}\left|S\left(d_{j}^{2}\right)-F_{0}\left(d_{j}^{2}\right)\right|
$$

dengan $S\left(d_{j}^{2}\right)$ = fungsi peluang kumulatif yang dihitung dari jarak mahalanobis.

$F_{0}\left(d_{j}^{2}\right)=$ fungsi peluang kumulatif dari distribusi Chi-Square.

Apabila kedua fungsi tersebut disajikan secara grafik maka $D$ adalah supremum antara $S\left(d_{j}^{2}\right)$ dan $F_{0}\left(d_{j}^{2}\right)$.

Kriteria Uji:

$$
H_{0} \text { ditolak jika } \mathrm{D}>\mathrm{D} *(\alpha)
$$

$\mathrm{D}^{*}(\alpha)$ merupakan nilai kritis yang diperoleh dari tabel Kolmogorov-Smirnov.

\subsection{Resampled Efficient Frontier}

Resampled Efficient Frontier secara optimal dapat mendefinisikan fungsi utilitas yang menggambarkan karakteristik dari preferensi risk-return investor. Resampled Efficient Frontier tidak begitu bergantung pada karakteristik variabel input. Resampled Efficient Frontier menggambarkan bobot portofolio yang tidak ekstrim dibandingkan dengan Mean Varian Efficiency (Michaud dan Michaud, 2008)

\subsection{Simulasi Monte-Carlo}

Ketidakstabilan dan sensitivitas yang tinggi dari hasil optimasi telah membawa manajer-manajer aset menambahkan metodologi lain dalam perhitungan optimasi portofolio dalam bentuk Simulasi Monte Carlo. Dalam kasus pengoptimalan portofolio, return tiap aset disimulasikan berdasarkan distribusi probabilitas return yang ditentukan dengan menguji distribusi empiris return historis (Rasmussen, 2003).

Menurut Rubinstein dan Melamed (1998), algoritma pembangkitan data normal multivariat dari a variabel sebanyak $\mathrm{n}$ data adalah sebagai berikut :

1. Membangkitkan $\boldsymbol{Z}_{\mathbf{1}}, \boldsymbol{Z}_{\mathbf{2}}, \ldots, \boldsymbol{Z}_{\boldsymbol{a}}$ dari distribusi $\mathrm{N}(0,1)$

2. Menentukan matriks $\mathbf{C}$, dimana matriks $\mathbf{C}$ adalah matriks segitiga bawah.

Matriks $\mathbf{C}$ dihitung dengan persaman berikut :

$$
c_{i j}=\frac{s_{i j}-\sum_{k=1}^{j-1} c_{i k} c_{j k}}{\left(s_{j j}-\sum_{k=1}^{j-1} c_{j k}\right)^{1 / 2}} ; \quad 1 \leq j \leq i \leq a
$$

Dengan ketentuan bahwa :

$$
\sum_{k=1}^{j-1} c_{i k} c_{j k}=0 ; \quad \text { untuk } j=1
$$

3. Menghitung variabel baru hasil pembangkitan

$$
\mathbf{V}=\mathbf{C Z} \circledast \overline{\boldsymbol{x}}
$$

Operator $\circledast$ menyatakan penjumlahan setiap kolom dari hasil perkalian $\mathbf{C Z}$ dengan $\overline{\boldsymbol{x}}$. Dalam hal ini $\overline{\boldsymbol{x}}$ adalah vektor mean, $\boldsymbol{S}$ adalah matriks varian kovarian, dan $\mathbf{V}$ adalah matriks dari variabel hasil pembangkitan. 
4. Langkah 1-3 diulangi sampai Q kali.

\subsection{Pembentukan Bobot dengan Meminimalkan Variansi}

Menurut Rasmussen (2003), portofolio dengan varian minimum adalah portofolio yang menghasilkan risiko terkecil berdasarkan karakteristik input tiap aset. Konstrain/batasan yang berlaku dalam portofolio ini hanya jumlah bobot aset yang harus sama dengan satu. Selanjutnya dapat dibentuk fungsi Lagrange L, dan akan dicari $\boldsymbol{w}$ yang meminimalkan fungsi tersebut.

$$
\begin{aligned}
& \text { meminimalkan } \boldsymbol{w}^{\boldsymbol{T}} \boldsymbol{S} \boldsymbol{w} \text { dengan syarat } \boldsymbol{w}^{\boldsymbol{T}} \mathbf{1}=1 \\
& \quad L=\boldsymbol{w}^{\boldsymbol{T}} \boldsymbol{S} \boldsymbol{w}-\lambda\left(\boldsymbol{w}^{\boldsymbol{T}} \mathbf{1}-1\right)
\end{aligned}
$$

Untuk portofolio dengan varian efisien, tidak ada batasan pada mean portofolio $(\lambda=0)$, sehingga pembobotan pada Mean Variance Efficient Portofolio adalah :

$$
w=\frac{S^{-1} 1}{1^{T} S^{-11}}
$$

Turunan kedua dari L terhadap $\boldsymbol{w}$ adalah sebagai berikut :

$$
\frac{\partial^{2} L}{\partial \boldsymbol{w}^{\boldsymbol{T}} \partial \boldsymbol{w}}=2 \boldsymbol{S}
$$

Dapat ditunjukkan bahwa $\boldsymbol{w}$ yang diperoleh benar-benar akan meminimalkan nilai $\mathrm{L}$, dengan syarat matriks $\mathbf{S}$ merupakan definit positif dan $\boldsymbol{w}$ yang diperoleh akan memberikan risiko yang minimal dibandingkan dengan $\boldsymbol{w}$ yang lain.

\subsection{Meminimalkan Risiko pada Tingkat Return Tertentu}

Menurut Rasmussen (2003), proses pembentukan bobot untuk portofolio dengan varian minimum pada tingkat return tertentu mensyaratkan dua batasan yaitu :

1. spesifikasi awal dari expected return $\bar{r}=\boldsymbol{w}^{\boldsymbol{T}} \overline{\boldsymbol{R}}$

2. Jumlah bobot atau proporsi dari portofolio yang dibentuk harus sama dengan 1 , yakni $\boldsymbol{w}^{\boldsymbol{T}} \mathbf{1}=1$

Selanjutnya dapat dibentuk fungsi Lagrange L, untuk meminimalkan varian guna mendapatkan bobot $\boldsymbol{w}$.

$$
\begin{gathered}
\text { meminimalkan } \boldsymbol{w}^{\boldsymbol{T}} \boldsymbol{S} \boldsymbol{w} \text { dengan syarat } \boldsymbol{w}^{\boldsymbol{T}} \mathbf{1}=1 \text { dan } \bar{r}=\boldsymbol{w}^{\boldsymbol{T}} \bar{R} \\
L=\boldsymbol{w}^{\boldsymbol{T}} \boldsymbol{S} \boldsymbol{w}-\lambda_{1}\left(\boldsymbol{w}^{\boldsymbol{T}} \bar{R}-\bar{r}\right)-\lambda_{2}\left(\boldsymbol{w}^{\boldsymbol{T}} \mathbf{1}-1\right)
\end{gathered}
$$

Terdapat dua kendala pada persamaan diatas yakni $\bar{r}=\boldsymbol{w}^{\boldsymbol{T}} \overline{\boldsymbol{R}}$ dan $\boldsymbol{w}^{\boldsymbol{T}} \mathbf{1}=1$ dengan derivatif parsial pertama $L$ untuk masing-masing $\left(\boldsymbol{w}, \lambda_{1}, \lambda_{2}\right)$, diperoleh solusi untuk fungsi L sebagai berikut :

Dengan

$$
\boldsymbol{w}_{e f}=\frac{1}{K_{4}}\left[\left(K_{3} \cdot \boldsymbol{S}^{-1} \mathbf{1}-K_{1} \cdot \boldsymbol{S}^{-1} \overline{\boldsymbol{R}}\right)+\left(K_{2} \cdot \boldsymbol{S}^{-1} \bar{R}-K_{1} \cdot \boldsymbol{S}^{-1} \mathbf{1}\right) \cdot \bar{r}\right]
$$

$$
\begin{aligned}
& K_{\mathbf{1}}=\mathbf{1}^{T} \boldsymbol{S}^{-1} \bar{R} ; K_{2}=\mathbf{1}^{T} S^{-1} \mathbf{1} ; K_{\mathbf{3}}=\bar{R}^{T} S^{-1} \bar{R} ; K_{\mathbf{4}}=K_{3} \cdot K_{2}-K_{\mathbf{1}}{ }^{2} \\
& \boldsymbol{w}: \text { vektor bobot tiap saham dalam portofolio } \\
& \boldsymbol{S}: \text { matriks varian kovarian return saham } \\
& \bar{R} \text { : vektor rata-rata return saham dalam portofolio } \\
& \bar{r} \text { : expected return portofolio } \\
& \mathbf{1} \text { : vektor satuan dengan dimensi a x } 1
\end{aligned}
$$




\subsection{Value at Risk (VaR)}

Menurut Dowd (2002), VaR didefinisikan sebagai jumlah kerugian maksimum yang mungkin akan diterima selama periode waktu tertentu pada tingkat kepercayaan tertentu. Perhitungan $V a R$ sangat bergantung pada dua parameter yaitu periode waktu $h p$ dan tingkat kepercayaan $\left(\alpha_{c l}\right)$. Kemudian menurut Best (1998), perhitungan VaR alokasi dana untuk portofolio sebesar $P$ maka $V a R$ dengan holding period hp dan tingkat kepercayaan $c l$ adalah:

\subsection{GUI MATLAB}

$$
\operatorname{VaR}(h p, c l)=-\left(\alpha_{c l} \sqrt{h p} \sqrt{\boldsymbol{w}^{\boldsymbol{T}} \boldsymbol{S} \boldsymbol{w}}\right) * P
$$

$h p$ : jangka waktu investasi (holding period)

$\alpha_{c l}$ : nilai kuantil pada distribusi Normal Standar pada tingkat kepercayaan $c l$

$P \quad$ : alokasi dana/modal untuk portofolio

Matlab merupakan sebuah singkatan dari Matrix Laboratory. Menurut Pusadan (2014), GUI pada Matlab merupakan sebuah aplikasi display dari Matlab yang mengandung tugas, perintah, atau komponen program yang mempermudah user atau pengguna dalam menjalankan sebuah program dalam Matlab.

\section{METODE PENELITIAN}

\subsection{Jenis dan Sumber Data}

Data yang digunakan dalam penelitian ini adalah data sekunder yang diunduh pada tanggal 2 November 2018 dari situs penyedia data historis saham yaitu http://finance.yahoo.com .

\subsection{Variabel Penelitian}

Variabel yang digunakan dalam penelitian ini adalah harga saham dari 4 saham anggota LQ45 periode Maret 2013 sampai Maret 2017. Saham yang dipilih adalah saham PT Bank Negara Indonesia (Persero) Tbk, PT United Tractors Tbk, PT Indah Kiat Pulp \& Paper Tbk, dan PT Kalbe Farma Tbk.

\subsection{Metode Analisis Data}

Metode analisis yang digunakan dalam penelitian in adalah metode Resampled Efficient Frontier dengan menggunakan Software Microsoft Excel 2010, Matlab R2015b, dan $\mathrm{R}$ i386 3.2.5. Berikut langkah-langkah yang dilakukan untuk menganalisis data dalam penelitian ini:

1. Mengumpulkan data observasi berupa harga bulanan historis $a$ aset saham sebanyak $\mathrm{n}+1$ data.

2. Menghitung return tiap aset saham berdasarkan harga saham bulanan sehingga didapatkan sebanyak $\mathrm{n}$ data return untuk tiap aset saham.

3. Melakukan uji normal multivariat dari a return saham. Jika uji normal multivariat ini tidak terpenuhi maka kembali melakukan langkah 1-3.

4. Menentukan jumlah titik efisien yang akan diobservasi, yaitu M titik efisien.

5. Mengestimasi parameter dari data return historis. Dalam hal ini parameter yang dibutuhkan adalah mean return dan matriks varian-kovarian return dari a aset saham.

6. Membangkitkan return baru menggunakan simulasi Monte Carlo berdasarkan parameter data return historis.

7. Mengestimasi nilai mean return dan matriks varian-kovarian return yang baru berdasarkan hasil simulasi.

8. Mengulangi langkah 6 dan 7 sebanyak Q kali untuk melakukan pembangkitan sehingga akan didapatkan estimasi mean return dan matriks varian-kovarian return sebanyak Q. 


$$
\begin{gathered}
\widehat{\boldsymbol{R}}_{1}=\left[\begin{array}{c}
\bar{R}_{1} \\
\vdots \\
\bar{R}_{a}
\end{array}\right], \ldots \ldots, \widehat{\boldsymbol{R}}_{Q}=\left[\begin{array}{c}
\bar{R}_{1} \\
\vdots \\
\bar{R}_{a}
\end{array}\right] \\
\widehat{\boldsymbol{S}}_{1}=\left[\begin{array}{cccc}
S_{11} & \ldots & S_{1 a} \\
\vdots & \ddots & \vdots \\
S_{a 1} & \ldots & S_{a a}
\end{array}\right], \ldots \ldots, \widehat{\boldsymbol{S}}_{Q}=\left[\begin{array}{ccc}
S_{11} & \ldots & S_{1 a} \\
\vdots & \ddots & \vdots \\
S_{a 1} & \ldots & S_{a a}
\end{array}\right]
\end{gathered}
$$

9. Menghitung bobot varian minimum untuk setiap skema Monte Carlo (setiap perulangan).

$$
w_{q_{\min }}=\frac{\widehat{\boldsymbol{S}}_{q}{ }^{-1} \mathbf{1}}{\mathbf{1}^{T} \widehat{\boldsymbol{S}}_{q}{ }^{-1} \mathbf{1}}
$$

10. Mengestimasi nilai return portofolio minimum berdasarkan bobot varian minimum untuk setiap Skema Monte Carlo.

$$
\bar{r}_{q_{\text {min }}}=\boldsymbol{w}_{\boldsymbol{q}_{\text {min }}} \boldsymbol{T}^{\widehat{\boldsymbol{R}}_{q}}
$$

11. Mengestimasi return portofolio maksimum dari aset-aset saham yang dimasukkan ke dalam portofolio.

$$
\bar{r}_{q_{\text {max }}}=\max \left\{\widehat{\boldsymbol{R}}_{q}{ }^{\boldsymbol{T}} \boldsymbol{\delta}^{(\mathbf{1})}, \ldots, \widehat{\widehat{\boldsymbol{R}}}_{q}{ }^{\boldsymbol{T}} \boldsymbol{\delta}^{(\boldsymbol{a})}\right\}
$$

Dengan $\delta$ merupakan canonical basis vektor sebagai berikut :

$$
\begin{gathered}
\boldsymbol{\delta}^{(\mathbf{1})}=(1,0, \ldots, 0)^{T} \\
\vdots \\
\boldsymbol{\delta}^{(\boldsymbol{a})}=(0,0, \ldots, 1)^{T}
\end{gathered}
$$

12. Menentukan interval return portofolio dari return portofolio minimum sampai return portofolio maksimum. Banyaknya return yang dihitung dalam interval tersebut sebanyak M titik untuk setiap skema Monte Carlo.

$$
\begin{gathered}
\bar{r}_{q}^{(1)}=\bar{r}_{q_{\text {min }}} \\
\bar{r}_{q}^{(M)}=\bar{r}_{q_{\text {max }}} \overline{\bar{r}}_{q_{\text {min }}}(m-1) \\
\bar{r}_{q}^{(m)}=\bar{r}_{q_{\text {min }}}+\frac{\bar{r}_{q_{\text {max }}}}{M-1}(m-1
\end{gathered}
$$

dengan $\mathrm{m}: 1,2,3, \ldots, \mathrm{M}$

$\mathrm{q}: 1,2,3, \ldots, \mathrm{Q}$

13. Menentukan bobot dari tiap titik efisien pada setiap skema Monte Carlo.

$$
\begin{gathered}
\boldsymbol{w}_{\boldsymbol{q}}^{(\boldsymbol{m})}=\min \boldsymbol{w}^{\boldsymbol{T}} \widehat{\boldsymbol{S}}_{\boldsymbol{q}} \boldsymbol{w} \\
\text { dengan syarat } \boldsymbol{w}^{\boldsymbol{T}} \mathbf{1}=1 \text { dan } \boldsymbol{w}^{\boldsymbol{T}} \widehat{\boldsymbol{R}}_{q}=\bar{r}_{q}^{(m)}
\end{gathered}
$$

14. Menghitung bobot akhir Resampled Efficient Frontier sebagai rata-rata bobot portofolio di setiap titik efisien.

$$
\boldsymbol{w}_{\boldsymbol{r} s}{ }^{(m)}=\frac{1}{Q} \sum_{q=1}^{Q} \boldsymbol{w}_{\boldsymbol{q}}^{(m)}
$$

$$
\text { M: } 1,2,3, . ., \mathrm{M}
$$

15. Menentukan rentang waktu investasi (holding period) 
16. Menentukan tingkat kepercayaan untuk mendapatkan nilai kuantil $\left(\alpha_{c l}\right)$ pada tingkat kepercayaan $\mathrm{cl}$ dari distribusi normal.

17. Menghitung nilai $\operatorname{VaR}$ distribusi normal multivariat pada tingkat kepercayaan $c l$ dan lama periode investasi $h p$ dengan alokasi modal $\mathrm{P}$ yaitu :

$$
\operatorname{VaR}(h p, c l)=-\left(\alpha_{c l} \sqrt{h p} \sqrt{\boldsymbol{w}^{\boldsymbol{T}} \boldsymbol{S} \boldsymbol{w}}\right) * P
$$

\section{HASIL DAN PEMBAHASAN}

\subsection{Pengujian Normalitas Return}

Pengujian asumsi normal multivariat dari return adalah sebagai berikut:

Hipotesis :

$$
\begin{aligned}
\mathrm{H}_{0}= & \text { Jarak Mahalanobis berdistribusi Chi Square } \\
& \text { (data return berdistribusi normal multivariat) } \\
\mathrm{H}_{1}= & \text { Jarak Mahalanobis tidak berdistribusi Chi Square } \\
& \text { (data return tidak berdistribusi normal multivariat) }
\end{aligned}
$$

Taraf Signifikansi : 5\%.

Statistik Uji :

$$
\mathrm{D}=0,17033 \text { dengan nilai } \mathrm{p} \text {-value }=0,05166
$$

Kriteria Uji :

$\mathrm{H}_{0}$ ditolak jika $\mathrm{D}>\mathrm{D}^{*}(\alpha)$ atau $\mathrm{p}$-value $<\alpha$

Keputusan :

Nilai $D^{*}(0.05)=0,19429$. Nilai $\mathrm{D}<\mathrm{D}^{*}(0.05)$ dan $\mathrm{p}$-value $>0.05$ maka $\mathrm{H}_{0}$ diterima.

Kesimpulan

Return BBNU, UNTR, INKP dan KLBF berdistribusi normal multivariat.

\subsection{Resampled Efficient Frontier}

Metode Resampling Efficient Frontier dalam penulisan Tugas Akhir ini di bawah asumsi normal, sesuai dengan prosedur Resampled Efficient Frontier yang dikemukakan oleh Michaud dan Michaud (2008). Untuk membangkitkan data return aset berdistribusi normal secara bersama-sama, parameter yang digunakan adalah mean dan varian data return historis. Berikut nilai mean dan varian tiap saham dari data return historis:

Tabel 1. Mean dan Varian Return tiap Saham

\begin{tabular}{ccc}
\hline Saham & Mean Return & Varian \\
\hline BBNI & 0,0048 & 0,0074 \\
UNTR & 0,008 & 0,0051 \\
INKP & 0,0176 & 0,0254 \\
KLBF & 0,005 & 0,0042 \\
\hline
\end{tabular}

Efficient frontier hasil Resampled Efficient Frontier menggunakan simulasi sebanyak 700 kali dengan 51 titik efisien. Penentuan jumlah titik efisien sebanyak 51 mengikuti penelitian yang dilakukan oleh Michaud dan Michaud (2008). Tiap titik efisien menggambarkan portofolio efisien dengan tingkat return dan risiko tertentu yang ada pada efficient frontier. Selanjutnya dari 51 portofolio efisien, diambil portofolio yang disesuaikan dengan karakteristik investor terhadap return dan risiko. 
Tabel 2. Portofolio yang Disesuaikan dengan Karakteristik Investor

\begin{tabular}{|c|c|c|c|c|c|c|c|}
\hline \multirow{2}{*}{$\begin{array}{c}\text { Tipe } \\
\text { Investor }\end{array}$} & \multirow{2}{*}{$\begin{array}{c}\text { Titik } \\
\text { Efisien } \\
\text { ke- }\end{array}$} & \multicolumn{4}{|c|}{ Bobot } & \multirow{2}{*}{$\begin{array}{c}\text { Return } \\
\text { Portofolio }\end{array}$} & \multirow{2}{*}{$\begin{array}{l}\text { Risiko } \\
\text { Portofolio }\end{array}$} \\
\hline & & BBNI & UNTR & INKP & KLBF & & \\
\hline $\begin{array}{c}\text { Risk } \\
\text { averter }\end{array}$ & 1 & $10,83 \%$ & $39,69 \%$ & $8,14 \%$ & $41,33 \%$ & 0,0072003 & 0,04996 \\
\hline $\begin{array}{c}\text { Moderate } \\
\text { investor }\end{array}$ & 26 & $10,42 \%$ & $42,11 \%$ & $19,67 \%$ & $27,79 \%$ & 0,016031 & 0,063462 \\
\hline $\begin{array}{l}\text { Risk } \\
\text { taker }\end{array}$ & 51 & $10,01 \%$ & $44,54 \%$ & $31,20 \%$ & $14,25 \%$ & 0,024861 & 0,090061 \\
\hline
\end{tabular}

Portofolio pada titik efisien pertama adalah portofolio yang tepat untuk risk averter Untuk tipe risk moderate, portofolio yang tepat adalah portofolio pada titik efisien ke-26. Sedangkan untuk risk taker portofolio yang tepat adalah portofolio pada titik efisien ke-51. Gambaran portofolio efisien pada tiap titik efisien disajikan dalam kurva efisien pada gambar 1.

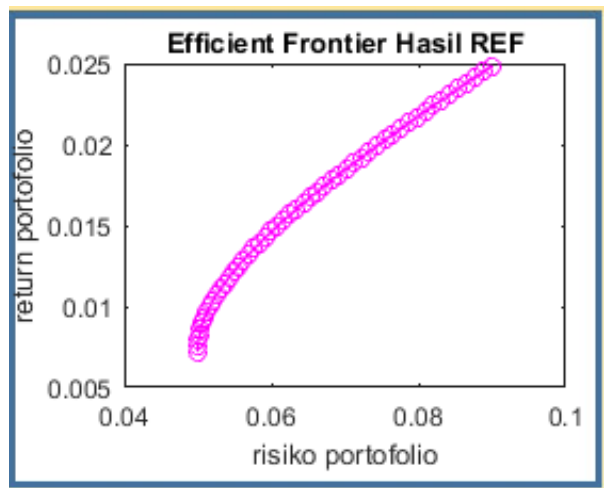

\subsection{Value at Risk (VaR)}

Gambar 1. Efficient Frontier dari REF

Dari portofolio optimal sebelumnya dihitung nilai VaR-nya untuk menggambarkan nilai kerugian maksimal yang mungkin akan diterima investor. Dengan masa investasi selama 20 hari, tingkat kepercayaan 95\% dan alokasi modal Rp 100,000,000.00 gambaran proporsi alokasi modal tiap portofolio beserta $V a R$-nya adalah sebagai berikut:

Tabel 3. Alokasi Modal dan VaR untuk Portofolio Berisiko Minimum

\begin{tabular}{cccccc}
\hline Saham & Bobot & Modal & Alokasi Modal & $\begin{array}{c}\text { Risiko } \\
\text { Portofolio }\end{array}$ & VaR \\
\hline BBNI & $10,83 \%$ & & $10.830 .000,00$ & & \\
UNTR & $39,69 \%$ & $100.000 .000,00$ & $\begin{array}{c}39.690 .000,00 \\
8.140 .000,00\end{array}$ & 0,04996 & $-36.780 .406,00$ \\
INKP & $8,14 \%$ & & $41.330 .000,00$ \\
KLBF & $41,33 \%$ & & \\
\hline \multicolumn{5}{c}{ Tabel 4. Alokasi Modal dan VaR untuk Portofolio Berisiko Menengah } \\
\hline Saham & Bobot & Modal & Alokasi Modal & Risiko & VaR \\
\hline BBNI & $10,42 \%$ & & $10.420 .000,00$ & & \\
UNTR & $42,11 \%$ & \multirow{2}{*}{$100.000 .000,00$} & $42.110 .000,00$ & 0,063462 & $-46.686 .599,00$ \\
INKP & $19,67 \%$ & $19.670 .000,00$ & & \\
KLBF & $27,79 \%$ & & $27.790 .000,00$ & & \\
\hline
\end{tabular}


Tabel 7. Alokasi Modal dan VaR untuk Portofolio Berisiko Maksimum

\begin{tabular}{cccccc}
\hline Saham & Bobot & Modal & Alokasi Modal & $\begin{array}{c}\text { Risiko } \\
\text { Portofolio }\end{array}$ & VaR \\
\hline BBNI & $10,01 \%$ & & $10.010 .000,00$ & & \\
UNTR & $44,54 \%$ & & & & \\
INKP & $31,20 \%$ & $100.000 .000,00$ & $44.540 .000,00$ & 0,090061 & $-66.255 .072,00$ \\
KLBF & $14,25 \%$ & & $31.200 .000,00$ & & \\
\hline
\end{tabular}

Untuk portofolio berisiko minimum, besaran risiko yang didapat dalam bentuk standar deviasi sebesar 0.064996 dengan nilai VaR sebesar $\mathrm{Rp} 36.780 .406,00$. Untuk portofolio berisiko menengah, besaran risiko yang didapat dalam bentuk standar deviasi sebesar 0.063462 dengan nilai VaR sebesar Rp 46.686.599,00. Sedangkan untuk portofolio berisiko tinggi, besaran risiko yang didapat dalam bentuk standar deviasi sebesar 0.090061 dengan nilai VaR sebesar Rp 66.255.072,00.

\subsection{Prosedur Penggunaan Aplikasi GUI Matlab}

Komputasi pemograman Resampled Efficient Frontier untuk perhitungan Value at Risk pada software Matlab dilakukan dalam penelitian ini. Software Matlab yang digunakan dalam penelitian ini adalah Matlab versi R2015b. Pemaparan tampilan dan cara penggunaan program GUI Matlab Resampled Efficient Frontier untuk perhitungan Value at Risk sebagai berikut:

1. Tampilan Home GUI Matlab Resampled Efficien Frontier untuk perhitungan Value at Risk dapat dilihat pada Gambar2.

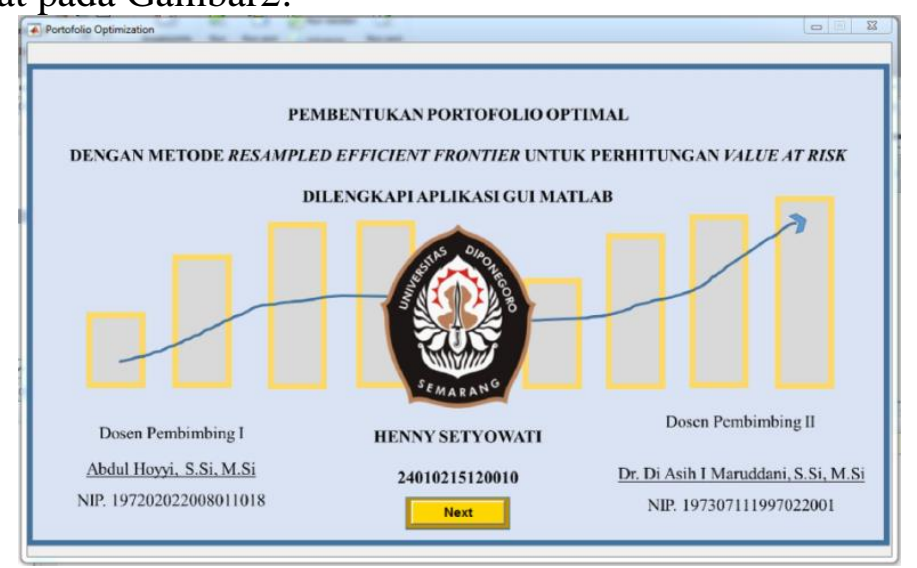

Gambar 2. Tampilan Home GUI Matlab Resampled Efficient Frontier untuk Perhitungan Value at Risk

2. Bagian dalam GUI Matlab Resampled Efficien Frontier untuk perhitungan Value at Risk dapat ditampilkan dengan melakukan klik pada tombol "Next", sehingga akan muncul tampilan seperti pada Gambar 3.

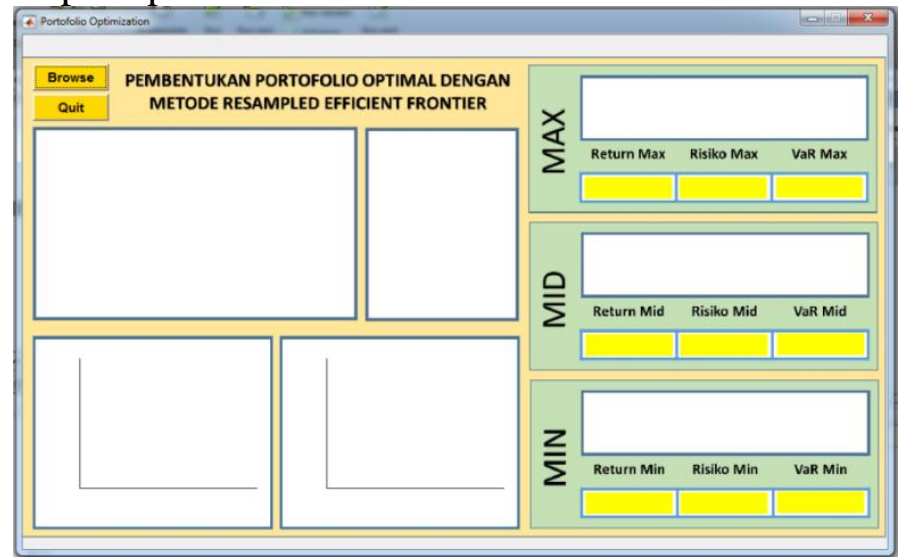


Gambar 3. Tampilan Analisis data GUI Matlab

3. Penginputan data beserta analisis data dilakukan dengan klik tombol "Browse". Data yang dimasukkan adalah data return dari data closing price data saham. Data dan hasil output-nya akan muncul pada tabel yang telah tersedia seperti pada Gambar 4.

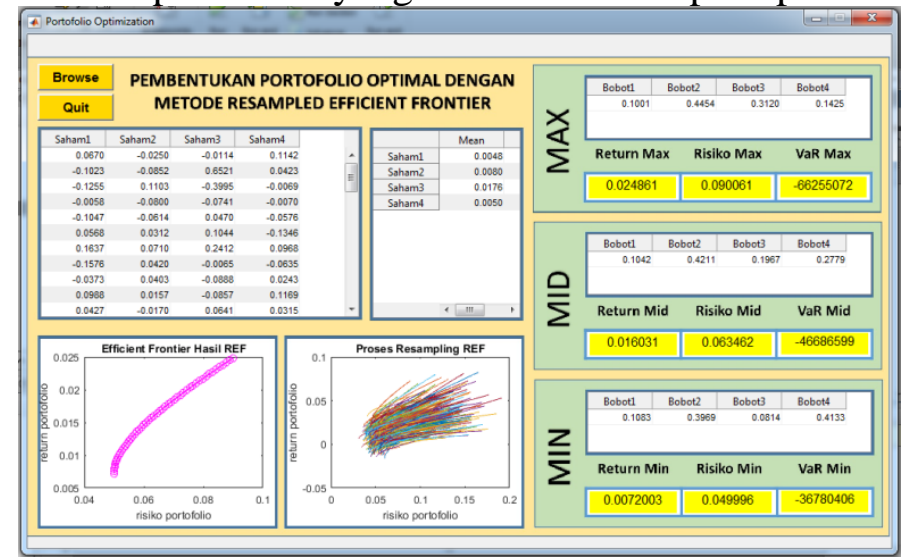

Gambar 4. Tampilan Tombol Input Data Sekaligus Run Data

4. Cara mengakhiri program yaitu dengan melakukan klik pada tombol "Quit" seperti pada Gambar 4.

\section{Kesimpulan}

Berdasarkan analisis yang telah dilakukan terhadap empat saham anggota LQ45 yaitu BBNI, UNTR, INKP dan KLBF dapat diambil kesimpulan sebagai berikut :

1. Berdasarkan metode Resampled Efficient Frontier dengan menggunakan 51 titik efisien, didapatkan portofolio optimal bagi risk averter berada di titik efisien ke-1, lalu untuk risk moderate berada pada titik efisien ke-26 dan bagi risk taker berada pada titik efisien ke-51.

2. Dengan mengalokasikan modal Rp $100,000,000.00$ pada ketiga portofolio optimal dengan holding period 20 hari dan tingkat kepercayaan 95\%, Value at Risk untuk portofolio optimal bagi risk averter adalah sebesar Rp 36.780.406,00. Sedangkan VaR dari portofolio optimal risk moderate dan risk taker masing-masing sebesar Rp 46.686.599,00 dan Rp 66.255.072,00.

\section{Daftar Pustaka}

Ang, R. 1995. Buku Pintar Pasar Modal Indonesia. Jakarta: Media Staff Indonesia.

Bodie, Z., Kane, A., dan Marcus, A.J. 2006. Investasi. Zuliani Dalimunthe dan Budi Wibowo, penerjemah. Jakarta: Salemba Empat. Terjemahan dari: Investments Sixth Edition.

Dowd, K. 2002. An Introduction to Market Risk Measurement. England: John Wiley \& Sons Ltd.

Fabozzi, F.J. 1999. Manajemen Investasi. Tim Penerjemah Salemba Empat, penerjemah. Jakarta: Salemba Empat. Terjemahan dari: Investment Managemant.

Maruddani, D.A.I., dan Purbowati, A. 2009. Pengukuran Value at Risk Pada Aset Tunggal dan Portofolio dengan Simulasi Monte Carlo. Media Statistika. Vol 2(2) : 93-104. Semarang.

Michaud, R.O. dan Michaud, R.O. 2008. Efficient Asset Management. New York: Oxford University Press, Inc.

Pusadan, M. Y. 2014. Pemrograman MATLAB pada Sistem Pakar Fuzzy. Yogyakarta: Deepublish. 
Rasmussen, M. 2003. Quantitative Portfolio Optimisation Asset Allocation and Risk Management. New York: Palgrave Macmillan.

Rubinstein, R.Y. dan Melamed, B. 1998. Modern Simulation and Modeling. New York: John Wiley \& Sons, Inc.

Samsul, M. 2006. Pasar Modal dan Manajemen Portofolio. Jakarta: PT Erlangga.

Tandelilin, E. 2010. Portofolio dan Investasi Teori dan Aplikasi, Edisi Pertama. Yogyakarta: Kanisius.

Usman, M. 1989. Pasar Modal Sebagai Piranti untuk Mengalokasikan Sumberdaya Ekonomi Secara Optimal Management \& Usahawan Indonesia. No. 10 Thn XVIII. 